\title{
ACCUMULATION OF CHEMICAL ELEMENTS BY ORGANS OF SPARGANIUM ERECTUM L. AND THEIR POTENTIAL USE IN PHYTOREMEDIATION PROCESS
}

\author{
Agnieszka Edyta Parzych ${ }^{1}$ \\ 1 Institute of Biology and Environmental Protection, Pomeranian University in Słupsk, 22 Arciszewskiego St., \\ 76-200 Słupsk, Poland, e-mail: parzycha1@op.pl
}

Received: 2015.11.12

Accepted: 2015.12.09

Published: 2016.01.06

\begin{abstract}
The study of bottom sediments and organs of Sparganium erectum carried out in the summer of 2014 in the city of Lębork, located in Northern Poland. The aim of this study was to evaluate the content of macroelements and heavy metals in the leaves, rhizomes and roots S. erectum and in bottom sediments of the Łeba River as well as comparison of accumulation and translocation factors of $\mathrm{N}, \mathrm{P}, \mathrm{K}, \mathrm{Mg}, \mathrm{Ca}, \mathrm{Zn}, \mathrm{Ni}, \mathrm{Cu}$, $\mathrm{Mn}, \mathrm{Fe}, \mathrm{Cd}$ and $\mathrm{Cr}$ in researched organs of aquatic plant. The use of $S$. erectum for biomonitoring and phytoremediation has also been considered. The results of Mann Whitney $\mathrm{U}$ test showed a number of statistically significant differences in the content of chemical elements in the leaves, rhizomes, roots and in bottom sediments. The macroelements are mainly accumulated in leaves and heavy metals are accumulated in roots and rhizomes of $S$. erectum. Increased $\mathrm{Mn}$ and $\mathrm{Fe}$ content in roots and rhizomes of $S$. erectum, in relation this physiological needs, refers to the beneficial effects of this species in the water treatment and sludge from the bottom sediment of manganese and iron compounds. The obtained bioconcentration and translocation factors values allowed to state that $S$. erectum can be used for phytoremediation of contaminated bottom sediments because retains metals in their roots and limit Mn and Fe mobility from roots and rhizomes to leaves once absorbed by roots of plant.
\end{abstract}

Keywords: macroelements, heavy metals, aquatic plant, bioaccumulation factor, translocation factor.

\section{INTRODUCTION}

Pollution of municipal ecosystems with substances of anthropogenic origin, including heavy metals, contributed to increase of concentration of macro and microelements in waters, bottom sediments and plants on banks of many rivers [Samecka-Cymerman and Kempers 2001, Parzych et al. 2015b]. Most chemical elements concentrated in river bottom sediments undergo bioaccumulation in living organisms, and in consequence the hazard of their contamination grows within the trophic chain, at the top of which there is the man. Absorption and bioaccumulation of necessary constituents by plants results especially from physiological demand and constitutes an element of natural circulation. The content of heavy metals in aquatic plants may exceed their content in the surrounding water environment many times [Aksoy et al., 2005], the wide range of variability is caused by biology and ecology of particular species. Macrophytes reflect the status of elements and chemical compounds pollution of water reservoirs very well [Baldantoni et al. 2009, Klink et al. 2013]. Some aquatic plants can remove macroelements [Miretzky et al. 2004, Parzych et al. 2015a] and heavy metals [Demirezen and Aksoy 2004, Deng et al. 2004, Vardanyan and Ingole 2006, Parzych et al. 2015b] from waters environments. In environments that are scarcely transformed by the man, pollution originates mainly from river estuaries and precipitation. In urban areas, substances originating from municipal, agricultural and industrial sew- 
age prevail. Some plant species developed certain defensive mechanisms which allow limitation of transport of hazardous compounds from roots and rhizomes to stems and leaves [Cardwell et al. 2002, Deng et al. 2004, Baldantoni et al. 2009, Parzych et al. 2015b]. The ability to uptake metals from the environment, even at low concentration, makes the aquatic macrophytes efficient indicators of the aquatic environment quality [Parzych et al. 2015a, b]. Sparganium erectum L. plant is a monocot, commonly occurring in Europe and Western Asia. It belongs to the family of Sparganiaceae. It appears both on sandy and gravel subsoil, however, it prefers loamy deposits. At the early stage of growth, the plant changes its form from submerged into emerged. S. erectum usually reaches up to 1.5 meters high [Szoszkiewicz et al. 2010] and has a high capacity for taking heavy metals into its organs [Vardanyan and Ingole 2006, Łojko et al. 2015]. High bioconcentration factor and high metal accumulation in organs of plant make them an interesting tool for phytoremediation, because it means that one species can absorb the maximum number of pollutants simultaneously [Sharma et al. 2015].

The tests related to parts of Sparganium erectum as to properties of accumulation of macro and micro elements, are still fragmentary and insufficient. Therefore, research has been done for their supplementation. The aim of this study was to evaluate the content of chemical elements in the leaves, rhizomes and roots Sparganium erectum L. and in bottom sediments of the Leba River as well as comparison of accumulation and translocation factors of $\mathrm{N}, \mathrm{P}, \mathrm{K}, \mathrm{Mg}, \mathrm{Ca}, \mathrm{Zn}, \mathrm{Ni}, \mathrm{Cu}, \mathrm{Mn}$, $\mathrm{Fe}, \mathrm{Cd}$ and $\mathrm{Cr}$ in researched organs of aquatic plant. The use of $S$. erectum for biomonitoring and phytoremediation has also been considered.

\section{MATERIAL AND METHODS}

\section{Study area}

Lębork is a town covering the area of 1786 ha with 35 thousand inhabitants, situated in the glacial valley of the Łeba-Reda River in Northern Poland $\left(54.549^{\circ} \mathrm{N} 17.750^{\circ} \mathrm{E}\right)$. Within the area of research, the vicinity of the Baltic Sea $(30 \mathrm{~km})$ is a decisive factor in development of weather conditions. Due to the short distance from the sea, in the research area relatively high air humidity is maintained with substantial overcast and little temperature amplitudes. The average air tem- perature was $9.7^{\circ} \mathrm{C}$ in 2014 . July was the warmest month $\left(20.5^{\circ} \mathrm{C}\right)$, and January was the coldest $\left(-1.3{ }^{\circ} \mathrm{C}\right)$. The annual precipitation level was $692 \mathrm{~mm}$. August was characterized by the highest level of precipitation $(121 \mathrm{~mm})$, and February the lowest $(9.8 \mathrm{~mm})$. Lębork is a center of electromachinery, food processing, mineral processing and light industry. Within the area of the town, there are some larger industrial enterprises whose activity has negative impact on the state of the air, surface waters and soil. The most arduous are: Electroplating Plant, Iron and Non-ferrous Metals Foundry, Construction Ceramics, Fish Processing Establishment and district boiler houses as well as boiler houses at housing estates.

\section{Sample collection and analytical methods}

The study was conducted in September 2014, within 8 stations ( $2 \mathrm{~km}$ part of the river) located throughout the city of Lębork. The samples of bottom sediments and of leaves, rhizomes and roots of Sparganium erectum originated from the littoral zone of the Łeba River. The bottom sediments were collected with the use of the Eckman sampler from the depth of $0-10 \mathrm{~cm}$. The samples were dried at $65{ }^{\circ} \mathrm{C}$ to a constant weight for approximately $48 \mathrm{~h}$, they were sieved through a sieve of $1 \mathrm{~mm}$ and grinded in a mortar. In bottom sediments acidity $(\mathrm{pH})$ and organic matter $(\mathrm{OM})$ content were indicatedwith a method of heat loss in a muffle furnace at the temperature $550{ }^{\circ} \mathrm{C}$ for $4 \mathrm{~h}$. The samples of Sparganium erectum within the area of each station were taken for the tests from several plants by preparation of mixed samples separately made of leaves (top leaf part and lower leaf part), and separately of rhizomes and separately of roots. The plant material was cleaned of mineral parts of the soil, washed in the distilled water, dried to constant mass at the temperature of $65^{\circ} \mathrm{C}$ for $48 \mathrm{~h}$. Then, it was homogenized in a laboratory grinder (IKA A11, Germany). The total contents of nitrogen in bottom sediments and in plants was determined by Kiejdahl method (Büchi K-350, Switzerland), and the phosphorus by the molybdate method (spectrophotometer UV-VIS, Hitachi U-5100, Japan), after digested in the mixture of $98 \% \mathrm{H}_{2} \mathrm{SO}_{4}$ and $30 \% \mathrm{H}_{2} \mathrm{O}_{2}(1: 1)$. In order to determine the metallic elements, the bottom sediments $(1.0 \mathrm{~g})$ and plant samples $(0.5$ g) were digested wet in a closed system, in the mixture of $65 \% \mathrm{HNO}_{3}$ (pro-analysis) and $30 \%$ $\mathrm{H}_{2} \mathrm{O}_{2}$ (pro-analysis) (1:1) under high temperature 
and pressure [Sobczyński et al. 1996]. Finally, the filtrate was made to $50 \mathrm{ml}$ with deionised water. The concentration of $\mathrm{K}, \mathrm{Mg}, \mathrm{Ca}, \mathrm{Zn}, \mathrm{Cu}, \mathrm{Ni}, \mathrm{Mn}$, $\mathrm{Fe}, \mathrm{Cd}$ and $\mathrm{Cr}$ in plants determined by atomic absorption spectrometry (AAS), (Aanalyst 300, Perkin Elmer, USA). The wavelengths at which the various metals were detected are as follows, K 769.9 nm, 202.6 Mg, 422.7 Ca, 213.9 Zn, 324.8 $\mathrm{Cu}, 232.0 \mathrm{Ni}, 279.5 \mathrm{Mn}, 248.3 \mathrm{Fe}, 228.8 \mathrm{Cd}$ and $357.9 \mathrm{Cr}$. The tests were carried out following the original standards of Merck (1g/1000 mL). All the results for bottom sediments and plants were calculated on a dry weight basis. All the analyses were performed in three replicates. The analytical quality of the results was checked against the following references materials: CRM 060 (aquatic plant) which were provided by the European Commission Institute for Reference Materials and Measurements. The recoveries were considered to be satisfactory if the results of the analysed elements were within the confidence intervals of the certified values.

\section{Statistical analysis}

The distribution of the content of the chemical elements (N, P, K, Mg, Ca, Zn, Cu, Ni, Mn, $\mathrm{Fe}, \mathrm{Cd}, \mathrm{Cr}$ ) in Sparganium erectum was tested by means of the Shapiro-Wilk test. Chemical composition of leaves, stems, rhizomes, roots and bottom sediments are presented in a form of a box and whisker plots containing the average, minimum, maximum and standard deviations. Classification of bottom sediments was made in accordance with the classification of Lawa [1998], which divides the sediments on the purity class as the increasing content of heavy metals (Table 1). It is assumed that the metal content in the dry matter of bottom sediments for classes I and I-II at the level of the geochemical background, while class II to IV indicate to the increasing influence of anthropogenic pollution of bottom sediments of rivers, and thus of the whole aquatic ecosystem.

The relationship between the content of chemical elements in organs of $S$. erectum and in bottom sediments was determined by bioconcentration factors (BCF) and translocation factors (TF). The BCF was calculated as the ratio: concentration of element in leaves (rhizomes, roots) concentration of element in bottom sediments [Zang et al. 2009]. Translocation factor was calculated as the ratio: concentration of element in leaves (rhizomes)/concentration of element in rhizomes (roots) according Bose et al. [2008]. Coefficient of variation $(\mathrm{CV}, \%)$ was calculated according to Wołek [2006]. The saliency of the diversity of the chemical elements content in leaves, rhizomes, roots of plant and in bottom sediments was evaluated by the non-parametric Mann Whitney $\mathrm{U}$ test $(\mathrm{N}=24)$, (Statistica 8.0).

\section{RESULTS AND DISSCUSION}

\section{Properties of bottom sediments}

Bottom sediments of the Leba River were characterized by low organic matter content (mean 3.8\%) demonstrating a diversity between the stations at the level of $26.3 \% 26.3 \%$ (Table 2 ). They had a little alkaline reaction with the $\mathrm{pH}$ levels from 7.5 to 7.7. Alkalinization of soil and water environment is often observed at mu-

Table 1. Classification of Lawa

\begin{tabular}{|c|c|c|c|c|c|c|c|}
\hline \multirow{2}{*}{ Metal, $\mathrm{mg} / \mathrm{kg}$} & \multicolumn{7}{|c|}{ Purity class } \\
\hline & I & I-II & II & II-III & III & III-IV & IV \\
\hline Zinc & $\leq 100$ & $\leq 200$ & $\leq 400$ & $\leq 800$ & $\leq 1600$ & $\leq 3200$ & $>3200$ \\
\hline Lead & $\leq 25$ & $\leq 50$ & $\leq 100$ & $\leq 200$ & $\leq 400$ & $\leq 800$ & $>800$ \\
\hline Copper & $\leq 20$ & $\leq 40$ & $\leq 80$ & $\leq 160$ & $\leq 320$ & $\leq 640$ & $>640$ \\
\hline Nickel & $\leq 30$ & $\leq 60$ & $\leq 120$ & $\leq 240$ & $\leq 480$ & $\leq 960$ & $>960$ \\
\hline Chrome & $\leq 80$ & $\leq 160$ & $\leq 320$ & $\leq 640$ & $\leq 1280$ & $\leq 2560$ & $>2560$ \\
\hline Cadmium & $\leq 0.3$ & $\leq 0.6$ & $\leq 1.2$ & $\leq 2.4$ & $\leq 4.8$ & $\leq 9.6$ & $>9.6$ \\
\hline Class I & \multicolumn{7}{|c|}{ Uncontaminated } \\
\hline Class I-II & \multicolumn{7}{|c|}{ Uncontaminated / Moderately contaminated } \\
\hline Class II & \multicolumn{7}{|c|}{ Moderately contaminated } \\
\hline Class II-III & \multicolumn{7}{|c|}{ Moderately contaminated / Heavily contaminated } \\
\hline Class III & \multicolumn{7}{|c|}{ Heavily contaminated } \\
\hline Class III-IV & \multicolumn{7}{|c|}{ Heavily / Very heavily contaminated } \\
\hline Class IV & \multicolumn{7}{|c|}{ Very heavily contaminated } \\
\hline
\end{tabular}


Table 2. Physico-chemical properties of bottom sediments of Łeba River ( $n=24)$

\begin{tabular}{|c|c|c|c|c|c|c|}
\hline \multicolumn{2}{|c|}{ Parameter } & $\begin{array}{c}\text { Mean } \pm \\
\text { Standard deviation }\end{array}$ & Minimum & Maximum & Variation coefficient, $\%$ & $\begin{array}{c}\text { Geochemical } \\
\text { background value }\end{array}$ \\
\hline \multicolumn{2}{|c|}{ OM, \% } & $3.8 \pm 0.9$ & 3.0 & 5.2 & 26.3 & - \\
\hline \multicolumn{2}{|c|}{$\mathrm{pH}$} & $7.52^{*} \pm 0.1$ & 7.5 & 7.7 & 1.4 & - \\
\hline $\mathrm{N}$ & \multirow{12}{*}{$\mathrm{mg} / \mathrm{kg}$} & $1330 \pm 180.7$ & 1120.0 & 1540.0 & 13.6 & - \\
\hline$P$ & & $715.3 \pm 4.5$ & 634.2 & 839.8 & 13.2 & - \\
\hline $\mathrm{K}$ & & $549.1 \pm 54.9$ & 495.4 & 604.8 & 10.0 & $86^{1}$ \\
\hline $\mathrm{Mg}$ & & $640.0 \pm 122.6$ & 494.3 & 784.0 & 19.2 & $1000-9000^{2}$ \\
\hline $\mathrm{Ca}$ & & $1059.5 \pm 166.4$ & 877.2 & 1257.2 & 15.7 & $3539^{1}$ \\
\hline $\mathrm{Zn}$ & & $34.2 \pm 33.9^{5}$ & $12.4^{5}$ & $84.7^{5}$ & $98.9^{5}$ & $48^{3}$ \\
\hline $\mathrm{Cu}$ & & $13.2 \pm 15.3$ & 4.9 & 36.1 & 115.1 & $6.0^{2,3}$ \\
\hline $\mathrm{Ni}$ & & $12.2 \pm 1.6$ & 10.3 & 13.6 & 12.9 & $5.0^{2,3}$ \\
\hline $\mathrm{Mn}$ & & $67.3 \pm 32.6^{5}$ & $32.1^{5}$ & $101.0^{5}$ & $48.4^{5}$ & $500^{2}$ \\
\hline $\mathrm{Fe}$ & & $5432.0 \pm 790.0$ & 4319.8 & 6143.3 & 14.5 & $15000^{4}$ \\
\hline $\mathrm{Cd}$ & & $1.8 \pm 1.5$ & 0.7 & 3.9 & 84.4 & $<0.5^{3}$ \\
\hline $\mathrm{Cr}$ & & $2.1 \pm 1.1$ & 0.5 & 2.9 & 53.9 & $5.0^{3}$ \\
\hline
\end{tabular}

OM - organic matter, *median, ${ }^{1}$ Boyd (1995), ${ }^{2}$ Kabata-Pendias and Pendias 1999, ${ }^{4}$ Bojakowska and Sokołowska (1998), ${ }^{3}$ (Woitke et al., 2003), ${ }^{5}$ Zaborowska, 2015.

nicipal areas and can be a result of eluviation of easily soluble acidic components as well as deposition of alkaline particulate matter originating mainly from coal combustion [Parzych and Jonczak 2014]. Nitrogen and phosphorus content in bottom river sediments remained at the level from 1120.0 to $1540.0 \mathrm{mg} / \mathrm{kg}(\mathrm{N})$ and 634.2 to $839.8 \mathrm{mg} / \mathrm{kg}(\mathrm{P})$ and did not raise any objections. The content of some metal elements $(\mathrm{K}, \mathrm{Cu}, \mathrm{Ni}$, Cd) exceeded the value of the geochemical background, (Table 2), [Boyd 1995, Kabata-Pendias and Pendias 1999, Woitke et al. 2003], which indicated pollution of river bottom sediments with these elements. According to Lawa [1998], classification of bottom sediments of the Leba River are uncontaminated by $\mathrm{Zn}, \mathrm{Cu}, \mathrm{Ni}$ and $\mathrm{Cr}$ (I purity class), Moderately contaminated/Heavily contaminated by Cd (II-III purity class), (Table 1). The results showed that the concentrations of chemical elements in the bottom sediments have the sequence of $\mathrm{Fe}>\mathrm{N}>\mathrm{Ca}>\mathrm{P}>\mathrm{Mg}>\mathrm{K}>\mathrm{Mn}>\mathrm{Zn}>\mathrm{C}$ $\mathrm{u}>\mathrm{Ni}>\mathrm{Cr}>\mathrm{Cd}$. Heavy metals penetrate waters of the Łeba River from the industry which is situated within the area of the city of Lębork. The natural value of $\mathrm{Cu}$ in river deposits usually did not exceed $20 \mathrm{mg} / \mathrm{kg}$ [Lis and Pasieczna 1995]. Disposal of untreated sewage from the foundry and its improper dumping causes penetration of metal ions, including copper, to rivers and river bottom sediments [Bojakowska and Sokołowska 1998]. River environment pollution takes place mainly due to mining and processing of copper ore, but it can also be an effect of pesticides applied in agriculture as well as fodder additives, and the effect of combustion of mineral fuels. Combustion of coal and liquid fuels as well as leakage from municipal and industrial waste dumps, waste from foundry and used up catalytic converters, constitute the source of nickel in the environment. The natural nickel content in river bottom deposits of most rivers in Poland is about $10 \mathrm{mg} / \mathrm{kg}$ [Lis and Pasieczna 1995]. Cadmium demonstrates relatively high mobility and is quickly fixated in river deposits and water reservoirs [Kabata-Pendias and Pendias 1999]. The natural cadmium levels in bottom deposits of various rivers is Poland are $2.0 \mathrm{mg} / \mathrm{kg}$ for the Vistula River [Helios-Rybicka 1991 ], $0.6 \mathrm{mg} / \mathrm{kg}$ for the Warta River [Bojakowska et al. 2006].

\section{Macroelements content in organs of Sparganium erectum}

The chemical elements content in the bottom sediments of the rivers and the sprouts of aquatic plants reflect the impact's influence of anthropogenic factors on the natural environment. The Sparganium erectum organs represented diversity in accumulation of macro- and microelements. The highest average content of nitrogen was found in top leaf part $(17710.0 \mathrm{mg} / \mathrm{kg})$, and the lowest in lower leaf part (7910.0 mg/kg), (Figure 1, Table 3). Phosphorus in the largest quantities was accumulated in the roots $(6147.6 \mathrm{mg} / \mathrm{kg})$ and 
rhizomes $(4320.9 \mathrm{mg} / \mathrm{kg})$ of S.erectum. Its content in plants depends on the abundance of the environment. Phosphorus decides about the speed of root system growth and at the same time specifies the capacity of a plant to intake water and nutrients [Grzebisz 2003]. As in the case of nitrogen, K (3194.1 - $4883.7 \mathrm{mg} / \mathrm{kg}), \mathrm{Ca}(10103.7$ - $13601.7 \mathrm{mg} / \mathrm{kg})$ and $\mathrm{Mg}(1703.8-1768.0 \mathrm{mg} /$ $\mathrm{kg}$ ) appeared in the largest quantities in leaves. In the case of magnesium, however, no statistical vital differences of $\mathrm{Mg}$ content were discovered in particular organs of S. erectum (Figure 1, Table 3, Table 6). Plants transport macro-components directly to leaves, which are cumulated mainly in underground parts; and it is connected with the defensive system of the plants. Macro-components play a vital role in various biological processes conditioning correct growth and development of plants. According to Sharma et al. [2006], higher concentration of macroelements in the leaves plants is fully substantiated due to the process of photosynthesis which takes place therein. Similar relations in the content of microelements in the leaves and rhizomes of aquatic plants were also presented in the studies of Vardanyan and Ingole [2006], Baldantoni et al. [2009], Klink et al. [2013] and Parzych et at., [2015b]. The results also indicate that the rhizomes and roots of the $S$. erectum contain significant amounts of macroelements and are a valuable reservoir of ingredients necessary for their growth and development. The plants with correct level of content of macrocomponents are more resistant to stress and create defensive mechanisms against surrounding pollutants [Grzebisz 2003].

\section{Heavy metals content in organs of Sparganium erectum}

The content of chemical elements in organs of the plants depends on the content and their bioavailability in the environment, and on the period of vegetation and the morphological part. The heavy metals content in the organs of $S$. erectum was substantially diversified. The highest levels of average zinc quantity were discovered in roots $(97.2 \mathrm{mg} / \mathrm{kg})$ and rhizomes $(31.6 \mathrm{mg} / \mathrm{kg})$, and the lowest, in leaves (17.9-26.3 mg/kg), (Table 3). Zn content in the organs of $S$. erectum was within the limits of the values permissible for plants (10-70 $\mathrm{mg} / \mathrm{kg}$ ), [Kabata-Pendias and Pendias 1999] except for roots with the determined values $>70 \mathrm{mg} /$ $\mathrm{kg}$ (Figure 1, Table 3). Zinc is an indispensable microelement of all plants [Deng et al. 2004]. The sufficient concentration in the leaves which covers physiological needs of most plants is within the limit of $15-30 \mathrm{mg} / \mathrm{kg}$ [Kabata-Pendias and Pendias 1999]. It is a metal generally introduced to surface waters along with municipal sewage and surface flow. The sources of $\mathrm{Zn}$ in the natural environment comprise, among others, industrial emission and combustion of coal. The content of zinc in the plants from the habitats which are heavily polluted can be very high, especially in leaves and roots. Similar relations in zinc distribution in aboveground and underground sprouts of various water plants were described in the works of Aksoy et al. [2005], Vardanyan and Ingole [2006], Klink et al., [2013] and Parzych et al., [2015b].

The organs of $S$. erectum accumulated copper in the quantities exceeding their physiologi-

Table 3. Concentration of chemical elements $(\mathrm{mg} / \mathrm{kg})$ in organs of Sparganium erectum $(\mathrm{n}=24)$ from the Łeba River

\begin{tabular}{|c|c|c|c|c|c|}
\hline Element & $\begin{array}{c}\text { Top } \\
\text { leaf part }\end{array}$ & $\begin{array}{c}\text { Lower } \\
\text { leaf part }\end{array}$ & Rhizomes & Roots & $\begin{array}{c}\text { Natural content } \\
\text { in plants }\end{array}$ \\
\hline $\mathrm{N}$ & $17710.0 \pm 2993$ & $7910.0 \pm 1218$ & $11410.0 \pm 1622$ & $8750.0 \pm 771$ & $13000-31000^{1}$ \\
\hline $\mathrm{P}$ & $2850.0 \pm 441$ & $3012.1 \pm 776$ & $4320.9 \pm 1559$ & $6147.6 \pm 4943$ & $1000-4000^{1}$ \\
\hline $\mathrm{K}$ & $3194.1 \pm 603$ & $4883.7 \pm 1039$ & $2183.6 \pm 349$ & $1469.8 \pm 666$ & $5000-12000^{1}$ \\
\hline $\mathrm{Mg}$ & $1703.8 \pm 210$ & $1768.0 \pm 638$ & $1719.6 \pm 101$ & $1559.8 \pm 371$ & $1000-4000^{1}$ \\
\hline $\mathrm{Ca}$ & $13601.7 \pm 2323$ & $10103.7 \pm 2122$ & $4075.7 \pm 2284$ & $6182.4 \pm 1940$ & $1000-33000^{1}$ \\
\hline $\mathrm{Zn}$ & $26.3 \pm 25^{3}$ & $17.9 \pm 9.8^{3}$ & $31.6 \pm 10.7^{3}$ & $97.2 \pm 44.7^{3}$ & $10-70^{2}$ \\
\hline $\mathrm{Cu}$ & $9.2 \pm 1.5$ & $3.4 \pm 2.4$ & $7.8 \pm 2.5$ & $14.7 \pm 3.9$ & $4-5^{2}$ \\
\hline $\mathrm{Ni}$ & $18.9 \pm 6.1$ & $23.2 \pm 6.6$ & $8.8 \pm 3.1$ & $30.8 \pm 31.2$ & $0.5-5.0^{2}$ \\
\hline $\mathrm{Mn}$ & $316.7 \pm 187^{3}$ & $1237.9 \pm 636^{3}$ & $2810.9 \pm 4679^{3}$ & $3685.2 \pm 1194.7^{3}$ & $10-25^{2}$ \\
\hline $\mathrm{Fe}$ & $409.8 \pm 132$ & $571.6 \pm 346$ & $7776.2 \pm 5688$ & $10475.0 \pm 4500$ & $5-375^{2}$ \\
\hline $\mathrm{Cd}$ & $0.1 \pm 0.2$ & $0.4 \pm 0.2$ & $0.3 \pm 0.2$ & $2.5 \pm 0.5$ & $0.05-0.2^{2}$ \\
\hline $\mathrm{Cr}$ & $5.7 \pm 2.6$ & $2.1 \pm 0.7$ & $1.7 \pm 2.5$ & $1.9 \pm 1.2$ & $0.02-1.0^{2}$ \\
\hline
\end{tabular}

${ }^{1}$ Ostrowska and Porębska 2002, ${ }^{2}$ Kabata-Pendias and Pendias 1999, ${ }^{3}$ Zaborowska, 2015. 
cal demand, not exceeding, however, the toxic level (>30 mg/kg), [Kabata-Pendias and Pendias 1999]. The largest quantities appeared in roots $(14.7 \mathrm{mg} / \mathrm{kg})$ and in the upper parts of leaves $(9.2 \mathrm{mg} / \mathrm{kg})$. Substantial quantity of copper in the leaves may be of atmospheric origin which, along with the depositing particulars, penetrates the tissues of $S$. erectum. Copper is an element of low mobility in plants; the value below 4-5 $\mathrm{mg} / \mathrm{kg}$ is sufficient to cover physiological needs of most plants, and is substantially diversified depending on the part of the plant, its developmental stage, variety and species [Kabata-Pendias and Pendias 1999]. Its average content in aboveground parts of water plants was demonstrated in the research studies of Skorbiłowicz and Wiater [2003] from 7.4 to $10.5 \mathrm{mg} / \mathrm{kg}$, Teuchies et al. [2013] from 4.2 to $6.2 \mathrm{mg} / \mathrm{kg}$ in sprouts of various macrophytes and Łojko et al. [2015] from 0.15 to $10.5 \mathrm{mg} / \mathrm{kg}$ in the leaves of S. erectum.

The average nickel content remained at the level $30.8 \mathrm{mg} / \mathrm{kg}$ in roots, $23.2-18.9 \mathrm{mg} / \mathrm{kg}$ in leaves and $8.8 \mathrm{mg} / \mathrm{kg}$ in rhizomes of $S$. erectum. $\mathrm{Ni}$ and $\mathrm{Cu}$ accumulated in organs of the water plant demonstrate pollution of river bottom sediments with these metals (Table 2). The natural nickel content in plants is usually $0.1-5.0 \mathrm{mg} / \mathrm{kg}$ [Kabata-Pendias and Pendias 1999], and in municipal agglomerations these values are usually higher, since nickel is easily bio-accumulated in water plants which are sensitive bioindicators in waters of [Sarosiek and Wożakowska-Natkaniec 1993]. Strong cumulative property of some macrophytes in reference to nickel are confirmed in research study of Salt and Kramer [2000] and Mays and Edwards [2001]. Nickel is easily accumulated by the plants and transported to their aboveground parts, and when in excess, it is accumulated in the roots [Kabata-Pendias and Pendias 1999].

The highest levels of manganese content were found in roots $(3685.2 \mathrm{mg} / \mathrm{kg})$ and rhizomes $(2810.9 \mathrm{mg} / \mathrm{kg}$ ) S. erectum (Fig. 1, Table 3). Physiological demand for manganese in most plants is diversified; usually a sufficient level is $10-25 \mathrm{mg} / \mathrm{kg}$ [Kabata-Pendias and Pendias 1999]. Concentration of about $500 \mathrm{mg} / \mathrm{kg}$ can be toxic for some species. The increased quantity of $\mathrm{Mn}$ in roots and rhizomes in relations to their physiological demand may be a species characteristic feature and may indicate a positive impact of $S$. erectum on cleaning waters and bottom sedi- ments of manganese compounds. Manganese concentrations are generally high in most plants as a consequence of its high availability in bottom sediments [Bonanno and Lo Giudice 2010]. According to Salem et al. [2014] this metal is easily moving within plants to the aboveground plant organs. The research study of Teuchies et al. [2013] and Łojko et al. [2015] confirm substantial cumulative property of leaves of some water plants, including $S$. erectum in relation to manganese.

In the case of iron, its highest content was discovered in the roots $(10475.0 \mathrm{mg} / \mathrm{kg})$ and rhizomes $(7776.2 \mathrm{mg} / \mathrm{kg}$ ) of $S$. erectum (Figure 1 , Table 3 ), and their concentration in leaves was substantially lower and remained at the level of $409.8-571.6 \mathrm{mg} / \mathrm{kg}$. The concentration of iron above highest values $500 \mathrm{mg} / \mathrm{kg}$ are considered as toxic to plants [Allen 1989]. According to Kabata-Pendias and Pendias [1999], Fe belongs to the low mobility elements in a plant and is mostly gathered in underground parts. The high content of iron and manganese in the rhizomes and roots of $S$. erectum can indicate accumulative properties of that species in reference to $\mathrm{Fe}$ and $\mathrm{Mn}$. At the same time, minor concentrations in the leaves (Figure 1, Table 3) indicate the existence of a protective barrier, lifting the transfer of iron and manganese compounds from the underground to aboveground organs [Hozina et al. 2001]. The presented results of the research study demonstrate a potential effectiveness of $S$. erectum in the processes of phytoremediation of bottom deposits polluted by these metals. They block pollutants accumulated in them, preventing their migration. The strong accumulation of $\mathrm{Fe}$ was described it the earlier literature in the case of rhizomes of Glyceria maxima [Parzych et al. 2015a, Parzych et al. 2015b].

From among the tested chemical elements, cadmium was found in the organs of $S$. erectum in the smallest quantities. In the roots, its content was found to be at the level of $2.5 \mathrm{mg} /$ $\mathrm{kg}$, in rhizomes $0.3 \mathrm{mg} / \mathrm{kg}$, and in leaves from 0.1 to $0.4 \mathrm{mg} / \mathrm{kg}$ (Figure 1, Table 3). Cadmium, as zinc, is a very easily taken in by roots and leaves of plants. Cd transport in a plant is easy, but with its more intensive intake, is accumulated in roots. According to Kabata-Pendias and Pendias [1999] Cd content in plants is substantially diversified, and in over-ground parts is usually $0.05-0.2 \mathrm{mg} / \mathrm{kg}$. Toxic symptoms appear usually with the content of $5-10 \mathrm{mg} / \mathrm{kg}$ for sen- 

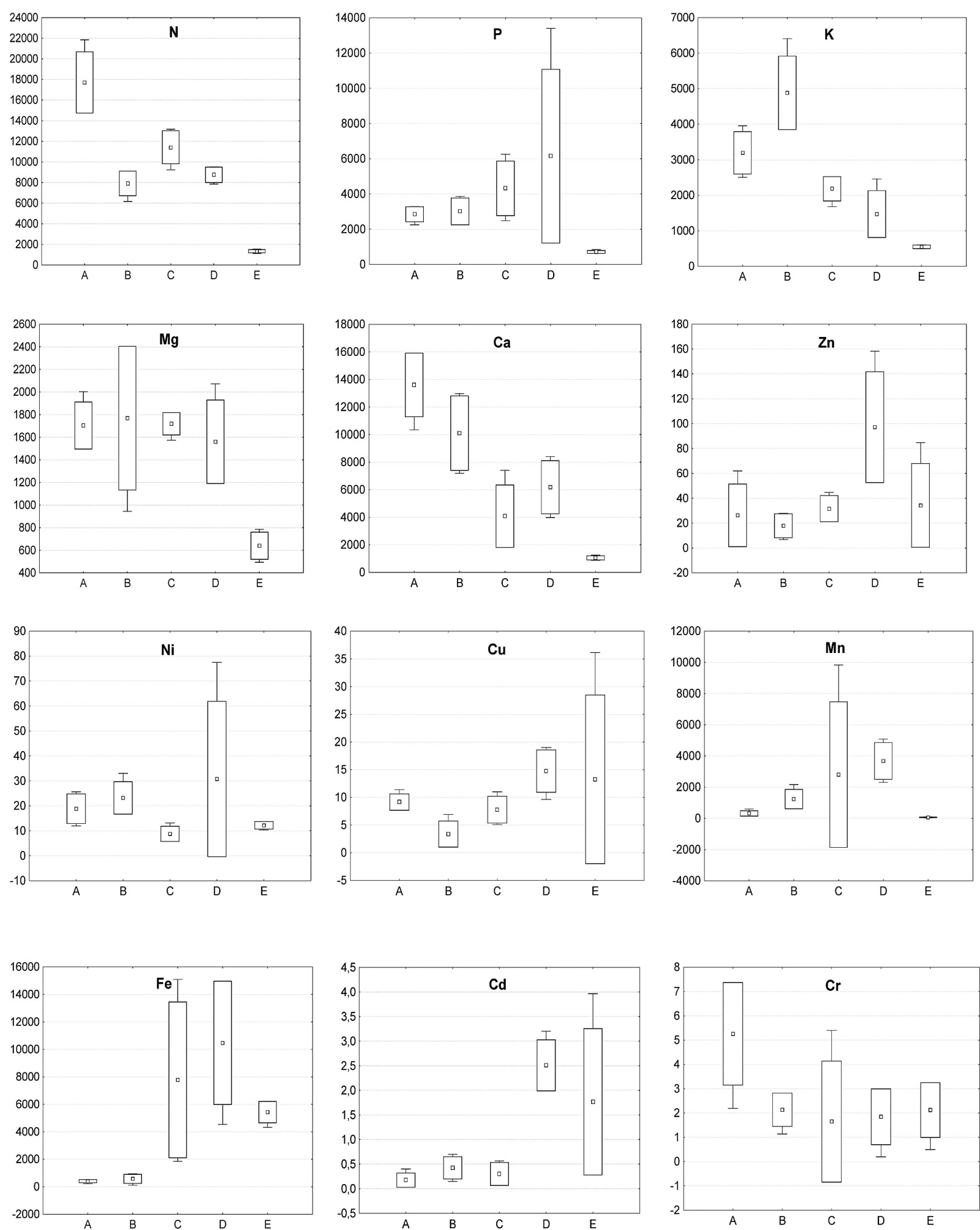

Figure 1. Variability of chemical elements contents $(\mathrm{mg} / \mathrm{kg})$ in organs of $S$. erectum and in bottom sediments of Łeba River: A - top leaf part, B - lower leaf part, C - rhizomes, D - roots, E - bottom sediments, box - mean \pm standard deviation, whiskers - minimum-maximum 
sitive plants, and $10-30 \mathrm{mg} / \mathrm{kg}$ for the resistant ones. Cadmium has a toxic effect on the plants, directly and indirectly by interactions with other heavy metals [Ostrowska et al. 1991].

Chromium was accumulated in the highest quantities in leaves $(5.7 \mathrm{mg} / \mathrm{kg}$ in top leaves part and $2.1 \mathrm{mg} / \mathrm{kg}$ in lower leaves part), and in the lowest in rhizomes $(1.7 \mathrm{mg} / \mathrm{kg})$ and roots $(1.9$ $\mathrm{mg} / \mathrm{kg}$ ) of S. erectum, (Figure 1, Table 3). In all samples, the levels exceeding the natural were found $(0.02-1.0 \mathrm{mg} / \mathrm{kg})$, which is the evidence of pollution of the Łeba River natural water environment. Chromium is taken in by plants in a passive way and it is not accumulated in large quantities. It is accumulated mainly in vegetative above-ground parts and roots and blocks intake of other components, such as: $\mathrm{Fe}, \mathrm{Mg}$ or Mn [Kabata-Pendias and Pendias 1999]. Different plants vary in their ability to accumulate $\mathrm{Cr}$ in tissues [Zayed et al., 1998].

\section{Bioconcentration and translocation factors}

The main factor deciding about the availability of chemical elements for $S$. erectum organs is the reaction of bottom sediments. Nitrogen is most available to plants at $\mathrm{pH}=6.0-8.0$, phosphorus at $\mathrm{pH}=6.5-8.0$, potassium, at $\mathrm{pH}=6.0-10.0$, and calcium and magnesium at $\mathrm{pH}=6.5-8.5$. Solubility of heavy metals is low as to neutral and alkaline reactions (Table 2), and increases along with lowering the value of $\mathrm{pH}$ [Smal and Salomons 1995]. Increase of mobility of $\mathrm{Zn}$ and $\mathrm{Mn}$ is most effective with $\mathrm{pH}=6$, while $\mathrm{Cu}$ and $\mathrm{Ni}$ at $\mathrm{pH}=5.5, \mathrm{Cr}$ at $\mathrm{pH}=3-4, \mathrm{Cd}$ at $\mathrm{pH}=3-5$ and $\mathrm{Fe}$ at $\mathrm{pH}=4$. Manganese, however, is character- ized by increased solubility also in alkaline environment [Alloway 1995, Kabata-Pendias and Pendias 1999].

Bioconcentration factors are a very important factor, because they indicate the possibility of using a plant in the process of phytoremediation. The presented values of indexes BCF (Table 4) represent diverse properties of accumulation of organs of $S$. erectum in relation to the tested chemical elements. In the upper part of the leaf, nitrogen and calcium was accumulated most intensively $(\mathrm{BCF}=13.3$ and 12.8 respectively), and in the lower part of the leaves, manganese, calcium and potassium $(\mathrm{BCF}=$ 18.4, 9.5 and 8.9), and manganese in rhizomes and roots $(\mathrm{BCF}=41.8$ and 54.7). High levels of $\mathrm{BCF}$ in reference to manganese are a species characteristic feature and the result of high bioavailability of $\mathrm{Mn}$ from bottom sediments due to beneficial levels of $\mathrm{pH}$ (Table 2). Plant can be used for phytostabilisation of contaminated bottom sediments because retains metal in their roots and limit manganese mobility from roots and rhizomes to leaves once absorbed by roots of plants [Cui et al. 2007]. It is assumed that when $\mathrm{BCF}=1$, the bottom sediments are the main source of origination of chemical elements. In the case of the level of $\mathrm{BCF}<10$, they are difficult to characterize since both bottom sediments and inflow pollutants can constitute the source of chemical elements [Chiarenzelli et al. 2001]. Different patterns in the accumulation of chemical elements between plants organs and bottom sediments were found in many studies [Bose et al. 2008, Sasmaz et al. 2009, Zang et al. 2009, Qian et al. 2012, Łojko et al. 2015].

Table 4. Bioconcentration factor (BCF) of chemical elements in organs of Sparganium erectum

\begin{tabular}{|c|c|c|c|c|}
\hline Element & $\begin{array}{c}\text { Top leaf part/ } \\
\text { bottom sediments }\end{array}$ & $\begin{array}{c}\text { Lower leaf part/ } \\
\text { bottom sediments }\end{array}$ & $\begin{array}{c}\text { Rhizomes/ } \\
\text { bottom sediments }\end{array}$ & $\begin{array}{c}\text { Roots/ } \\
\text { bottom sediments }\end{array}$ \\
\hline $\mathrm{N}$ & 13.3 & 5.9 & 8.6 & 6.6 \\
\hline $\mathrm{P}$ & 3.9 & 4.2 & 6.0 & 8.6 \\
\hline $\mathrm{K}$ & 5.8 & 8.9 & 3.9 & 2.7 \\
\hline $\mathrm{Mg}$ & 2.7 & 2.8 & 2.7 & 6.1 \\
\hline $\mathrm{Ca}$ & 12.8 & 9.5 & 3.8 & 2.8 \\
\hline $\mathrm{Zn}$ & 0.8 & 0.5 & 0.9 & 1.1 \\
\hline $\mathrm{Cu}$ & 0.7 & 0.3 & 0.6 & 2.5 \\
\hline $\mathrm{Ni}$ & 1.6 & 1.9 & 0.7 & 54.7 \\
\hline $\mathrm{Mn}$ & 4.7 & 18.4 & 41.8 & 1.9 \\
\hline $\mathrm{Fe}$ & 0.07 & 0.1 & 1.4 & 1.4 \\
\hline $\mathrm{Cd}$ & 0.06 & 0.2 & 0.2 & 0.9 \\
\hline $\mathrm{Cr}$ & 2.7 & 1.0 & 0.8 & \\
\hline
\end{tabular}


The translocation factor (TF) generally showed the mobility of chemical elements from roots to rhizomes and from rhizomes to leaves. On this basis, we can evaluate the ability of plants to phytoextraction. $\mathrm{TF}>1$ represent that translocation of chemical elements effectively was made from root to the shoot [Baker and Brooks 1989]. In the research related to $S$. erectum, obtained TF vales were from 0.1 to 2.7 (Table 5). In the case of nitrogen, potassium and magnesium, the values of TF $>1$ indicate easy flow of these chemical elements from roots to rhizomes. Heavy metals and phosphorus and calcium are characterized by substantially lower mobility, which is confirmed by the values of $\mathrm{TF}<1$. The values of translocation coefficients in the case of $\mathrm{Cr}$ (2.7 and 1.2) and $\mathrm{Ca}$ (1.3 and 2.5) prove that $S$. erectum can be potentially used in processes of phytoextraction due to the ease of translocation of these metals form roots to leaves (Table 5), [Yoon et al. 2006]. In water environment of the Łeba River, sufficient quantities of $\mathrm{N}, \mathrm{K}, \mathrm{Mg}$ and $\mathrm{Ca}$ (Table 3 ), were found, which indicates that in a free access to them from bottom sediments (Table 2), S. erectum transports them directly to the leaves (BCF $>1$, Table 4), $(\mathrm{TF}>1$, Table 5).

The results of the non-parametric Mann Whitney U test showed a number of statistically significant differences in the content of chemical elements in the leaves, rhizomes, roots and bottom sediments of the Leba River (Table 6). Potassium and nitrogen were included into the

Table 5. Translocation factor (TF) of chemical elements in organs of Sparganium erectum

\begin{tabular}{|c|c|c|c|c|}
\hline Element, mg/kg & $\begin{array}{c}\text { Top leaf part/ } \\
\text { Lower leaf part }\end{array}$ & $\begin{array}{c}\text { Lower leaf part/ } \\
\text { Rhizomes }\end{array}$ & $\begin{array}{c}\text { Rhizomes/ } \\
\text { Roots }\end{array}$ & $\begin{array}{c}\text { Top leaf part/ } \\
\text { Roots }\end{array}$ \\
\hline $\mathrm{N}$ & 2.2 & 0.7 & 1.3 & 2.0 \\
\hline $\mathrm{P}$ & 0.9 & 0.7 & 0.7 & 0.5 \\
\hline $\mathrm{K}$ & 0.6 & 2.2 & 1.5 & 1.1 \\
\hline $\mathrm{Mg}$ & 0.9 & 1.0 & 1.1 & 2.2 \\
\hline $\mathrm{Ca}$ & 1.3 & 2.5 & 0.7 & 0.3 \\
\hline $\mathrm{Zn}$ & 1.5 & 0.6 & 0.3 & 0.6 \\
\hline $\mathrm{Cu}$ & 2.7 & 0.4 & 0.5 & 0.6 \\
\hline $\mathrm{Ni}$ & 0.8 & 2.6 & 0.3 & 0.1 \\
\hline $\mathrm{Mn}$ & 0.3 & 0.4 & 0.8 & 0.09 \\
\hline $\mathrm{Fe}$ & 0.7 & 0.1 & 0.7 & 0.04 \\
\hline $\mathrm{Cd}$ & 0.2 & 1.3 & 0.1 & 3.0 \\
\hline $\mathrm{Cr}$ & 2.7 & 1.2 & 0.9 & \\
\hline
\end{tabular}

Table 6. Statistical significance of differences of chemical elements content in organs of Sparganium erectum and in bottom sediments (U-Manna Whitneya test, $\mathrm{n}=24$ )

\begin{tabular}{|c|c|c|c|c|c|c|c|c|c|c|}
\hline Element & $\mathrm{A}-\mathrm{B}$ & $\mathrm{A}-\mathrm{C}$ & $\mathrm{A}-\mathrm{D}$ & $\mathrm{A}-\mathrm{E}$ & $\mathrm{B}-\mathrm{C}$ & $\mathrm{B}-\mathrm{D}$ & $\mathrm{B}-\mathrm{E}$ & $\mathrm{C}-\mathrm{D}$ & $\mathrm{C}-\mathrm{E}$ & $\mathrm{D}-\mathrm{E}$ \\
\hline $\mathrm{N}$ & ++ & + & + & +++ & + & $\mathrm{ns}$ & + & $\mathrm{ns}$ & + & + \\
\hline $\mathrm{P}$ & $\mathrm{ns}$ & $\mathrm{ns}$ & $\mathrm{ns}$ & ++ & $\mathrm{ns}$ & $\mathrm{ns}$ & + & $\mathrm{ns}$ & + & + \\
\hline $\mathrm{K}$ & + & + & + & ++ & + & + & + & $\mathrm{ns}$ & + & + \\
\hline $\mathrm{Mg}$ & $\mathrm{ns}$ & $\mathrm{ns}$ & $\mathrm{ns}$ & ++ & $\mathrm{ns}$ & $\mathrm{ns}$ & + & $\mathrm{ns}$ & ++ & + \\
\hline $\mathrm{Ca}$ & $\mathrm{ns}$ & + & + & ++ & $\mathrm{ns}$ & $\mathrm{ns}$ & ++ & $\mathrm{ns}$ & + & + \\
\hline $\mathrm{Zn}$ & $\mathrm{ns}$ & $\mathrm{ns}$ & $\mathrm{ns}$ & $\mathrm{ns}$ & $\mathrm{ns}$ & + & $\mathrm{ns}$ & + & $\mathrm{ns}$ & $\mathrm{ns}$ \\
\hline $\mathrm{Cu}$ & + & $\mathrm{ns}$ & $\mathrm{ns}$ & $\mathrm{ns}$ & $\mathrm{ns}$ & + & $\mathrm{ns}$ & $\mathrm{ns}$ & $\mathrm{ns}$ & $\mathrm{ns}$ \\
\hline $\mathrm{Ni}$ & $\mathrm{ns}$ & $\mathrm{ns}$ & $\mathrm{ns}$ & $\mathrm{ns}$ & + & $\mathrm{ns}$ & + & $\mathrm{ns}$ & $\mathrm{ns}$ & $\mathrm{ns}$ \\
\hline $\mathrm{Mn}$ & + & $\mathrm{ns}$ & ++ & + & $\mathrm{ns}$ & + & + & $\mathrm{ns}$ & + & + \\
\hline $\mathrm{Fe}$ & $\mathrm{ns}$ & + & ++ & ++ & + & + & + & $\mathrm{ns}$ & $\mathrm{ns}$ & $\mathrm{ns}$ \\
\hline $\mathrm{Cd}$ & $\mathrm{ns}$ & $\mathrm{ns}$ & ++ & + & $\mathrm{ns}$ & + & $\mathrm{ns}$ & + & + & $\mathrm{ns}$ \\
\hline $\mathrm{Cr}$ & $\mathrm{ns}$ & $\mathrm{ns}$ & $\mathrm{ns}$ & $\mathrm{ns}$ & $\mathrm{ns}$ & $\mathrm{ns}$ & $\mathrm{ns}$ & $\mathrm{ns}$ & $\mathrm{ns}$ & $\mathrm{ns}$ \\
\hline
\end{tabular}

A - top leaf part, B - lower leaf part, C - rhizomes, D - roots, E - bottom sediments, A - top leaf part, B - lower leaf part, $\mathrm{C}$ - rhizomes, D - roots, $\mathrm{E}$ - bottom sediments, $\mathrm{ns}$ - no significance, + significance level of $\mathrm{p}<0.05,++$ significance level of $\mathrm{p}<0.01,+++$ significance level of $\mathrm{p}<0.001$. 
chemical elements characterized by the most frequent diversification. In the case of chromium, no statistically significant differences were found in concentration between the examined organs.

\section{CONCLUSIONS}

Bottom sediments of the Leba River were characterized by a slightly alkaline reaction and diverse content of organic matter. The reaction of bottom sediments promoted bioavailability of $\mathrm{N}, \mathrm{P}, \mathrm{K}, \mathrm{Mg} \mathrm{Ca}$ and $\mathrm{Mn}$. Bottom sediments were classified into class I of purity due as far as the content of $\mathrm{Zn}, \mathrm{Cu}, \mathrm{Ni}$ and $\mathrm{Cr}$ is concerned and to II-III class due to the presence of Cd. The results showed that the concentrations of chemical elements in the bottom sediments have the sequence of $\mathrm{Fe}>\mathrm{N}>\mathrm{Ca}>\mathrm{P}>\mathrm{Mg}>\mathrm{K}>\mathrm{Mn}>\mathrm{Zn}>\mathrm{Cu}>\mathrm{Ni}>\mathrm{Cr}>\mathrm{C}$.

Accumulative properties of $S$. erectum were diversified in relation to the examined chemical elements. The macroelements mainly are accumulated in leaves and the heavy metals are accumulated in the roots and rhizomes of $S$. erectum. The chemical elements accumulation in organs of $S$. erectum showed a trends of:

- $\mathrm{N}>\mathrm{Ca}>\mathrm{K}>\mathrm{P}>\mathrm{Mg}>\mathrm{Fe}>\mathrm{Mn}>\mathrm{Zn}>\mathrm{Ni}>\mathrm{Cu}>\mathrm{Cr}>\mathrm{C}$ $\mathrm{d}$ in top part leaves,

- $\mathrm{Ca}>\mathrm{N}>\mathrm{K}>\mathrm{P}>\mathrm{Mg}>\mathrm{Mn}>\mathrm{Fe}>\mathrm{Ni}>\mathrm{Zn}>\mathrm{Cu}>\mathrm{Cr}>\mathrm{C}$ $\mathrm{d}$ in lower part leaves,

- $\mathrm{N}>\mathrm{Fe}>\mathrm{P}>\mathrm{Ca}>\mathrm{Mn}>\mathrm{K}>\mathrm{Mg}>\mathrm{Zn}>\mathrm{Ni}>\mathrm{Cu}>\mathrm{Cr}>\mathrm{C}$ $\mathrm{d}$ in rhizomes, and

- $\mathrm{Fe}>\mathrm{N}>\mathrm{Ca}>\mathrm{P}>\mathrm{Mn}>\mathrm{Mg}>\mathrm{K}>\mathrm{Zn}>\mathrm{Ni}>\mathrm{Cu}>\mathrm{Cd}>\mathrm{C}$ $r$ in roots.

The results of the non-parametric Mann Whitney U test showed a number of statistically significant differences in the content of macroelements and heavy metals in the leaves, rhizomes, roots and bottom sediments. Increased $\mathrm{Mn}$ and $\mathrm{Fe}$ content in roots and rhizomes of $S$. erectum in relation this physiological needs refers to the beneficial effects of this species in the water treatment and sludge from the bottom sediment of manganese and iron compounds. The obtained bioconcentration and translocation factors values allowed to state that $S$. erectum can be used for phytoremediation of contaminated bottom sediments because retains metals in their roots and limit manganese and iron mobility from roots and rhizomes to leaves once absorbed by roots of plants.

\section{REFERENCES}

1. Aksoy A., Demirezen D., Duman F. 2005. Bioaccumulation, detection and analyses of heavy metal pollution in Sultan marsh and its environment. Water Air Soil Poll. 164, 241-255.

2. Allen S.E. 1989. Analysis of ecological materials. 2nd ed. Blackwell Scientific Publications, Oxford.

3. Alloway B.J., 1995. Soil processes and the behavior of metals. In: Alloway B.J. (Ed.) Heavy metals in soils. 2nd ed. Blackie, Glasgow, 7-28.

4. Baker A.J.M., Brooks R.R. 1989. Terrestrials higher plants which hyper accumulate metallic elements. A review of their distribution, ecology and phytochemistry. Biorecovery 1, 81-26.

5. Baldantoni D., Ligrone R., Alfania A. 2009. Macro- and trace-element concentration in leaves and roots of Phragmites australis in volcanic lake in Southern Italy. J. Geochem. Explor. 101, 166-174.

6. Bojakowska, I., Sokołowska G., 1998. Geochemical sediments class purity water. Przegląd Geologiczny 46, 1, 49-54.

7. Bojakowska I., Gliwicz T., Małecka K., 2006. Geochemical research results of water sediments in Poland 2003-2005. The Library of Environment Monitoring. Natural Environment Protection Inspectorate. Warsaw.

8. Bonanno G., Lo Giudice R., 2010. Heavy metal bioaccumulation by the organs of Phragmites australis (common reed) and their potential use as contamination indicators. Ecol. Indic. 10, 639-645.

9. Bose S., Chandrayan S., Rai V., Bhattacharya A.K., Ramanathan A.L. 2008. Translocation of metals in pea plants grown on various amendment of electroplating industrial sludge. Biores. Technol. 99, 4467-4475.

10. Boyd C.E. 1995. Bottom soils, sediment, and pond aquaculture. Chapman \& Hall, New York.

11. Cardwell A.J., Hawker D.W., Greenway M. 2002. Metal accumulation in aquatic macrophytes from southeast Queensland, Australia. Chemosphere 48, 653-663.

12. Chiarenzelli J.R., Aspler L.B., Dunn C., Cousens B., Ozarko D.L., Powis K.B. 2001. Multielements and rare earth element composition of lichens, mosses and vascular plants from Central Barrenlands. Nunavut, Canada. Appl. Geochem, 16, 245-270.

13. Cui S., Zhou Q., Chao L. 2007. Potential hyper-accumulation of $\mathrm{Pb}, \mathrm{Zn}, \mathrm{Cu}$ and $\mathrm{Cd}$ in endurant plants distributed in an old smeltery, northeast China. Environ. Geol., 51, 1043-1048.

14. Demirezen D., Aksoy A. 2004. Accumulation of heavy metals in Typha angustifolia (L.) and Potamogeton pectinatus (L.) living in Sultan Marsh 
(Kayseri Turkey). Chemosphere 56, 685-696.

15. Deng H., Ye Z.H., Wong M.H. 2004. Accumulation of lead, zinc, copper and cadmium by 12 wetland plant species thriving in metal-contaminated sites in China. Environ. Pollut. 132, 29-40.

16. Grzebisz W. 2003. Mechanisms of collection of phosphorus by the plant. In: Elements in the environment. Phosphorus. J. Elem. 8, 3, 33-46.

17. Helios-Rybicka E. 1991. Phase-specific bonding of heavy metals in the sediments of the Vistula River, Poland. Appl. Geochem. 2, 45-48.

18. Hozhina E.I., Khramov A.A., Gerasimov P.A., Kumarkov A.A. 2001. Uptake of heavy metals, arsenic, and antimony by aquatic plants in the vicinity of ore mining and processing industries. J. Geochem. Explor. 74, 153-164.

19. Kabata-Pendias A., Pendias H. 1999. Biogeochemistry of trace elements. Polish Scientific Publishing, Warszawa.

20. Klink A., Wisłocka M., Musiał M., Krawczyk J. 2013. Macro- and trace-elements accumulation in Typha angustifolia L. and Typha latifolia L. organs and their use in bioindication. Pol. J. Environ. Stud. 22, 1, 183-190.

21. Lawa 1998. Landesarbeitsgemeinschaft Wasser: Beurteilung der Wasserbeschaffen-heit von Fließgewässern in der Bundesrepublik Deutschland - chemische Gewässergüteklassifikation, Zielvorgaben zum Schutz oberirdischer binnengewässer - Band 2, Berlin.

22. Lis J., Pasieczna A. 1995. Geochemical atlas of the city and area. PIG, Warszawa.

23. Łojko R., Polechońska L., Klink A., Kosiba P. 2015. Trace metal concentrations and their transfer from sediment to leaves of four common aquatic macrophytes. Environ. Sci. Pollut. Res. 22, 19, 15123-31. doi: 10.1007/s11356-015-4641-1.

24. Mays P.A., Edwards G.S. 2001. Comparison of heavy metal accumulation in a natural wetland and constructed wetlands receiving acid mine drainage. Ecol. Eng., 16, 487-500.

25. Miretzky P., Saralegui A., Cirelli A.F. 2004. Aquatic macrophytes potential for the simultaneous removal of heavy metals (Buenos Aires, Argentina). Chemosphere 57, 997-1005.

26. Ostrowska A., Porębska G. 2002. The chemical composition of plants, its interpretation and use in environmental protection. Institute of Environmental Protection, Warsaw.

27. Ostrowska A., Gawliński S., Szczubiałka Z. 1991. Methods of analysis and evaluation of soil properties and plant. Institute of Environmental Protection, Warsaw.

28. Parzych A., Jonczak J. 2014. Pine needles (Pinus sylvestris L.) as bioindicators in the assessment of urban environmental contamination with heavy metals. J. Ecol. Eng. 15, 3, 29-38.

29. Parzych A., Cymer M., Jonczak J., Szymczyk S. 2015a. The ability of leaves and rhizomes of aquatic plants to accumulate macro- and micronutrients. J. Ecol. Eng., 16, 3, 198-205.

30. Parzych A., Sobisz Z., Cymer M. 2015b. Preliminary research of heavy metals content by aquatic macrophytes taken from surface water (northern Poland). Desalination and Water Treatment. 1-11. doi:10.1080/19443994.2014.1002275.

31. Qian Y., Gallagher F.J., Feng H., Wu M. 2012. A geochemical study of toxic metal translocation in an urban brownfield wetland. Environ. Pollut. 166, 23-30.

32. Salem Z.B., Laffray X., Ashoour A., Ayadi H., Aleya L. 2014. Metal accumulation and distribution in the organ of reeds and cattails in a constructed treatment wetland (Etueffont, France). Ecol. Eng. 64, 1-17.

33. Salt D.E., Kramer U. 2000. Mechanisms of metal hyperaccumulation in plants, phytoremediation of toxic metals: Using plants to clean up the environment. In: I. Raskin and B.D. Ensley (Eds.), Wiley and Sons, 231-246.

34. Samecka-Cymerman A., Kempers A.J. 2001. Concentrations of heavy metals and plant nutrients in water, sediments and aquatic macrophytes of anthropogenic lakes (former open cut brown coal mines) differing in stage of acidification. Sci. Total Environ. 281, 87-98.

35. Sarosiek J., Wożakowska-Natkaniec H. 1993. Chromium and nickel in plants of the Family Lemnaceae and in their environment. In: A. Kabata-Pendias (Ed.) Chromium, nickel and aluminum ecological problems and methodical. Zeszt. Nauk PAN. Kom. Człowiek i środowisko 5, 49-54.

36. Sasmaz A., Obek E., Hasar H. 2009. The accumulation of heavy metals in Typha latifolia L. grown in a stream carrying secondary effluent. Ecol. Eng. 33, 278-284.

37. Sharma P., Asaeda T., Manatunge J., Fijino T. 2006. Nutrient cycling in a natural stand of Typha angustifolia. J. Freshwater Ecol. 21, 431-438.

38. Sharma S., Singh B., Manchanda V.K. 2015. Phytoremediation: role of terrestrial plants and aquatic macrophytes in the remediation of radionuclides and heavy metal contaminated soil and water. Environ. Sci. Pollut. Res. 22, 946-962.

39. Skorbiłowicz E., Wiater, J. 2003. Estimation of water environment of Nereśl River the course section within peat bogs and swamps area. Acta Agrophysica 1, 1, 183-190.

40. Smal H., Salomons W. 1995. Acidification and its long-term impact on metal mobility, In: Bio- 
geodynamics of pollutants in soils and sediments. Springer-Verlag, Berlin, 193-212.

41. Sobczyński T., Elbanowska H., Zerze J., Siepak J. 1996. Digestion of samples of bottom sediments prior to the determination of total contents of heavy metals, Gospodarka Wodna 6, 173-175.

42. Szoszkiewicz K., Zbierska J., Jusik S., Zgoła T. 2010. Makrofitowa Metoda Oceny Rzek. Podręcznik metodyczny do oceny i klasyfikacji stanu ekologicznego wód płynących w oparciu o rośliny wodne. Wyd. Nauk. Bogucki, Poznań.

43. Teuchies J., Jacobs S., Oosterlee L., Bervoets L., Meire P. 2013. Role of plants in metal cycling in a tidal wetland: Implications for phytoremediation, Sci. Total Environ. 445-446, 146-154.

44. Vardanyan L.G., Ingole B.S. 2006. Studies on heavy metal accumulation in aquatic macrophytes from Sevan (Armenia) and Carambolim (India) lake system. Environ. Int. 32, 208-218.

45. Woitke P., Wellmitz J., Helm D., Kube P., Lepom P., Litheraty P. 2003. Analysis and assessment of heavy metal pollution in suspended solids and sediments of the river Danube. Chemosphere 51, 633-642.

46. Wołek J. 2006. Introduction to Statistics for biologists, Wyd. Nauk. Pedagogical Akademy, Kraków.

47. Yoon J., Cao X., Zhou Q., Ma L.Q. 2006. Accumulation of $\mathrm{Pb}, \mathrm{Cu}$ and $\mathrm{Zn}$ in native plants growing on a contaminated Florida site. Sci. Total. Environ., 368: 456-464.

48. Zaborowska A. 2015. Zinc and manganese accumulation in the shoot Sparganium erectum and bottom sediments of Leba River in Lębork. Pomerania Academy, mscr, Słupsk.

49. Zang M., Cui L., Sheng L., Wang Y. 2009. Distribution and enrichment of heavy metals among sediments, water body and plants in Hengshuihu Wetland of Northern China. Ecol. Eng. 35, 563-569.

50. Zayed A., Lytle C.M., Qian J.H., Terry N. 1998. Chromium accumulation, translocation and chemical speciation in vegetable crops. Planta 206, 293-299. 